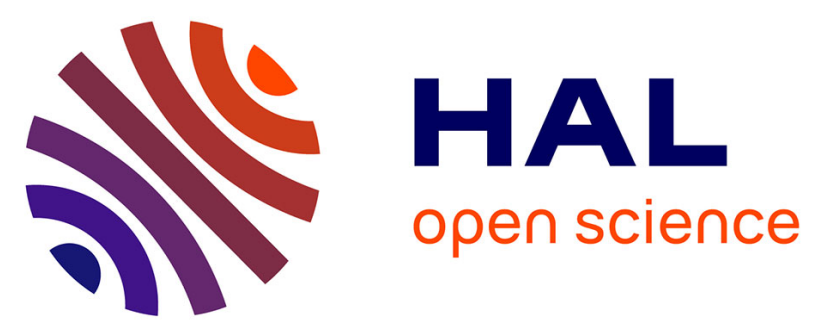

\title{
First mononuclear organometallics of MoII and MoIII containing terminal hydroxide ligands. X-Ray structure of $[\mathrm{Mo}(\eta 5-\mathrm{C} 5 \mathrm{H} 5)(\mathrm{OH})(\mathrm{PMe} 3) 3] \mathrm{BF} 4$
}

James C Fettinger, Heinz-Bernhard Kraatz, Rinaldo Poli, E. Alessandra Quadrelli

\section{To cite this version:}

James C Fettinger, Heinz-Bernhard Kraatz, Rinaldo Poli, E. Alessandra Quadrelli. First mononuclear organometallics of MoII and MoIII containing terminal hydroxide ligands. X-Ray structure of $[\mathrm{Mo}(\eta 5-$ C5H5)(OH)(PMe3) 3]BF4. Chemical Communications, 1997, 9, pp.889-890. 10.1039/A701616F . hal-03370824

\section{HAL Id: hal-03370824 \\ https://hal.science/hal-03370824}

Submitted on 8 Oct 2021

HAL is a multi-disciplinary open access archive for the deposit and dissemination of scientific research documents, whether they are published or not. The documents may come from teaching and research institutions in France or abroad, or from public or private research centers.
L'archive ouverte pluridisciplinaire HAL, est destinée au dépôt et à la diffusion de documents scientifiques de niveau recherche, publiés ou non, émanant des établissements d'enseignement et de recherche français ou étrangers, des laboratoires publics ou privés. 


\title{
First mononuclear organometallics of $\mathrm{Mo}^{\mathrm{II}}$ and $\mathrm{Mo}^{\mathrm{III}}$ containing terminal hydroxide ligands. X-Ray structure of $\left[\mathrm{Mo}\left(\eta^{5}-\mathrm{C}_{5} \mathrm{H}_{5}\right)(\mathrm{OH})\left(\mathrm{PMe}_{3}\right)_{3}\right] \mathrm{BF}_{4}$
}

\author{
James C. Fettinger, ${ }^{a}$ Heinz-Bernhard Kraatz, ${ }^{b}$ Rinaldo Poli*a,c and E. Alessandra Quadrelli ${ }^{a}$ \\ a Department of Chemistry and Biochemistry, University of Maryland, College Park, Maryland 20742, USA \\ b Steacie Institute for Molecular Science, National Research Council of Canada, 100 Sussex Drive, Ottawa, Canada, K1N 0R6 \\ c Laboratoire de Synthèse et d'Electrosynthèse Organometallique, Faculté des Sciences "Gabriel”, Université de Bourgogne, \\ 6 Boulevard Gabriel, 21100 Dijon, France
}

The new complexes [Mo $\left.\left(\eta^{5}-\mathrm{C}_{5} \mathrm{H}_{5}\right)(\mathrm{OH})\left(\mathrm{PMe}_{3}\right)_{2}\right]$ and $\left[\mathrm{Mo}\left(\eta^{5}-\mathrm{C}_{5} \mathrm{H}_{5}\right)(\mathrm{OH})\left(\mathrm{PMe}_{3}\right)_{3}\right]+$ are unique examples of electronically unsaturated organometallics of $\mathrm{Moll}^{\prime \prime}$ and $\mathrm{Mol}^{\prime \prime \prime}$ containing terminal hydroxide ligands; they show no tendency to dimerize with formation of hydroxo-bridges.

Hydroxide ligands are ubiquitous of Werner-type coordination chemistry, whereas they are less commonly found in organometallic compounds. The availability of lone pairs on the oxygen atom frequently leads a terminal hydroxide complex (I) to lose ligands and afford doubly or triply bridged oligomers, e.g. II and III. ${ }^{1-4}$ Organometallic compounds with terminal hydroxide ligands have rarely been observed for early- and latetransition-metal systems, ${ }^{5-10}$ and for low-oxidation state saturated (18-electron) systems with tightly bonded ancillary ligands, examples of which are $\left[\mathrm{Mo}(\mathrm{OH})(\mathrm{NO})(\mathrm{dppe})_{2}\right]^{11}$ and $\left[\mathrm{W}(\mathrm{CO})_{5}(\mathrm{OH})\right]^{-} .12 \mathrm{We}$ consider it therefore quite surprising to find the existence and stability toward dimerization of a mononuclear and paramagnetic organometallic $\mathrm{Mo}^{\mathrm{II}}$ hydroxo complex with a 16-electron configuration. To the best of our knowledge, there are only two previous examples of formally 16-electron $\mathrm{Mo}^{\mathrm{II}}$ complexes with terminal $\mathrm{OH}$ ligands, i.e. $[\mathrm{MoL}(\mathrm{NO})(\mathrm{O})(\mathrm{OH})](\mathrm{L}=1,4,7$-triisopropyl-1,4,7-triazacyclononane), and its corresponding protonated form, [MoL$\left.(\mathrm{NO})(\mathrm{OH})_{2}\right]^{+} .{ }^{13}$ These, however, do not contain $\mathrm{M}-\mathrm{C}$ bonds and are diamagnetic, probably because extra $\pi$ donation from the oxo lone pair(s) renders the compounds effectively saturated.

The reaction of $\left[\mathrm{Mo}\left(\eta^{5}-\mathrm{C}_{5} \mathrm{H}_{5}\right) \mathrm{Cl}\left(\mathrm{PMe}_{3}\right)_{3}\right]^{14}$ with dry $\mathrm{KOH}$ in thf leads to the exchange of the chloride ion and the formation of paramagnetic $\left[\mathrm{Mo}\left(\eta^{5}-\mathrm{C}_{5} \mathrm{H}_{5}\right)(\mathrm{OH})\left(\mathrm{PMe}_{3}\right)_{2}\right] \mathbf{1}$ [eqn. (1)]. $\dagger$ The

$\left[\mathrm{Mo}\left(\eta^{5}-\mathrm{C}_{5} \mathrm{H}_{5}\right) \mathrm{Cl}\left(\mathrm{PMe}_{3}\right)_{3}\right]+\mathrm{KOH} \rightarrow$

$$
\left[\mathrm{Mo}\left(\eta^{5}-\mathrm{C}_{5} \mathrm{H}_{5}\right)(\mathrm{OH})\left(\mathrm{PMe}_{3}\right)_{2}\right]+\mathrm{KCl}+\mathrm{PMe}_{3}
$$

same transformation occurs in $\mathrm{C}_{6} \mathrm{D}_{6}$, allowing the observation of 1 equiv. of free $\mathrm{PMe}_{3}$ by a ${ }^{1} \mathrm{H}$ NMR monitoring experiment (Fig. 1). The ${ }^{1} \mathrm{H}$ NMR spectrum of 1 shows contact-shifted resonances at $\delta 21.8$ and 20.3 in the correct ratio for the $\mathrm{PMe}_{3}$ and $\mathrm{C}_{5} \mathrm{H}_{5}$ protons. The ${ }^{31} \mathrm{P}$ NMR spectrum shows only the resonance of free $\mathrm{PMe}_{3}$. The compound is extremely soluble in saturated hydrocarbons, thus preventing its isolation in crystalline form. The formulation of the complex as mononuclear rather than dinuclear is based on a comparison with literature analogues: $\left[\mathrm{Mo}\left(\eta^{5}-\mathrm{C}_{5} \mathrm{Me}_{5}\right) \mathrm{ClL}_{2}\right]\left(\mathrm{L}=\mathrm{PMe}_{3}, \mathrm{PMe}_{2} \mathrm{Ph}\right.$ or $\mathrm{L}_{2}=$ dppe $)$ and $\left[\mathrm{Mo}\left(\eta^{5}-\mathrm{C}_{5} \mathrm{H}_{5}\right) \mathrm{Cl}\left(\mathrm{PMe}_{2} \mathrm{Ph}\right)_{2}\right]$ are also mononuclear paramagnetic $(S=1)$ complexes, ${ }^{15}$ and show contact-

$\mathrm{L}_{n} \mathrm{M}-\mathrm{OH}$

I

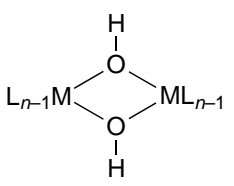

II

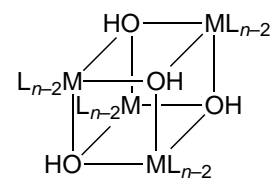

III shifted ${ }^{1} \mathrm{H}$ NMR resonances similar to those of $\mathbf{1}$. On the other hand, $\left[\left\{\mathrm{Mo}\left(\eta^{5}-\mathrm{C}_{5} \mathrm{H}_{5}\right)(\mu-\mathrm{Br})\left(\eta^{4}-\mathrm{C}_{4} \mathrm{H}_{6}\right)\right\}_{2}\right]$ is dinuclear and diamagnetic. ${ }^{16}$ Mononuclear 16 -electron $\left[\mathrm{Mo}\left(\eta^{5}-\mathrm{C}_{5} \mathrm{H}_{5}\right) \mathrm{XL}_{2}\right]$ complexes also exist with a spin-singlet ground state, ${ }^{17}$ whereas there are no paramagnetic 18-electron complexes in this class. A bis( $\mu$-hydroxo) dimeric structure for $\mathbf{1}$ is therefore ruled out.

It is rather peculiar that $\mathbf{1}$ is stable not only toward dimerization, but also toward coordination of the $\mathrm{PMe}_{3}$ ligand [eqn. (1)]. The corresponding chloro parent compound does not have any tendency to lose the third $\mathrm{PMe}_{3}$. However, sterically more encumbered $\left[\mathrm{Mo}\left(\eta^{5}-\mathrm{C}_{5} \mathrm{Me}_{5}\right) \mathrm{Cl}\left(\mathrm{PMe}_{3}\right)_{3}\right]$ and $\left[\mathrm{Mo}\left(\eta^{5}-\right.\right.$ $\left.\left.\mathrm{C}_{5} \mathrm{H}_{5}\right) \mathrm{Cl}\left(\mathrm{PMe}_{2} \mathrm{Ph}\right)_{3}\right]$ exist in equilibrium with the corresponding 16-electron bis-phosphine complexes. ${ }^{15}$ This behaviour is in line with the greater $\pi$-donating ability of $\mathrm{OH} v s$. $\mathrm{Cl}$. The paramagnetism of $\mathbf{1}$ parallels that of the chloro analogues, but is in contrast with the diamagnetism of the phosphido or arsenido derivatives $\left[\mathrm{Mo}\left(\eta^{5}-\mathrm{C}_{5} \mathrm{Me}_{5}\right)\left(\mathrm{PPh}_{2}\right) \mathrm{L}_{2}\right]^{17}$ and $\left[\mathrm{Mo}\left(\eta^{5}-\mathrm{C}_{5} \mathrm{H}_{5}\right)(\mathrm{As}-\right.$ $\left.\mathrm{Bu}_{2}{ }_{2}(\mathrm{CO})_{2}\right] .{ }^{18}$ We have previously rationalized this phenomenon in terms of differences in MO interactions (single-sided $v s$. double-sided $\pi$ donors) and pairing energy stabilization. ${ }^{15,19}$ Elaborating on those arguments, the paramagnetism of $\mathbf{1}$ might suggest the involvement of both oxygen lone pairs in two orthogonal two-centre-three electron interactions. ${ }^{20}$

Further treatment of the $1-\mathrm{PMe}_{3}$ solution in thf with $\left[\mathrm{Fe}\left(\eta^{5}-\right.\right.$ $\left.\left.\mathrm{C}_{5} \mathrm{H}_{5}\right)_{2}\right] \mathrm{BF}_{4}$ leads to at least two products. Crystallization from acetone-heptane affords yellow needles of $\left[\mathrm{Mo}\left(\eta^{5}\right.\right.$ $\left.\left.\mathrm{C}_{5} \mathrm{H}_{5}\right)(\mathrm{OH})\left(\mathrm{PMe}_{3}\right)_{3}\right] \mathrm{BF}_{4} 2$ and red cubes of $\left[\mathrm{Mo}\left(\eta^{5}-\mathrm{C}_{5} \mathrm{H}_{5}\right) \mathrm{O}(\mathrm{P}-\right.$ $\left.\left.\mathrm{Me}_{3}\right)_{2}\right] \mathrm{BF}_{4}$ 3. The structure of 2 (Fig. 2) $\ddagger$ shows a terminal mode for the hydroxide ligand in the expected four-legged piano-stool geometry, as found ${ }^{14}$ for the related $\left[\mathrm{Mo}\left(\eta^{5}\right.\right.$ $\left.\left.\mathrm{C}_{5} \mathrm{H}_{5}\right) \mathrm{Cl}\left(\mathrm{PMe}_{3}\right)_{3}\right]^{+}$. The structural parameters are normal for this class of compounds, ${ }^{21}$ with the Mo-O bond measuring 2.084(2) $\AA$. To the best of our knowledge, 2 is the first reported organometallic hydroxide of $\mathrm{Mo}^{\mathrm{III}}$, and the first complex of Mo ${ }^{\mathrm{III}}$ (including Werner-type and clusters) with a terminally bonded hydroxide. ${ }^{22-25} \mathrm{~A}$ deprotonated form of the $\mathrm{Mo}^{\mathrm{III}}$ aquo complex $\left[\mathrm{Mo}\left(\mathrm{H}_{2} \mathrm{O}\right)_{6}\right]^{3+}$ is known, but this corresponds to a $\mu$-hydroxo dimer, i.e. $\left[\left\{\mathrm{Mo}\left(\mathrm{H}_{2} \mathrm{O}\right)_{4}(\mu-\mathrm{OH})\right\}_{2}\right]^{4+} .26 \mathbf{3}$ has been previously reported. ${ }^{27} \S$

The formation of $\mathbf{2}$ by oxidation of $\mathbf{1}$ occurs according to the stoichiometry of eqn. (2). Half-sandwich $\mathrm{Mo}^{\mathrm{III}}$ complexes are

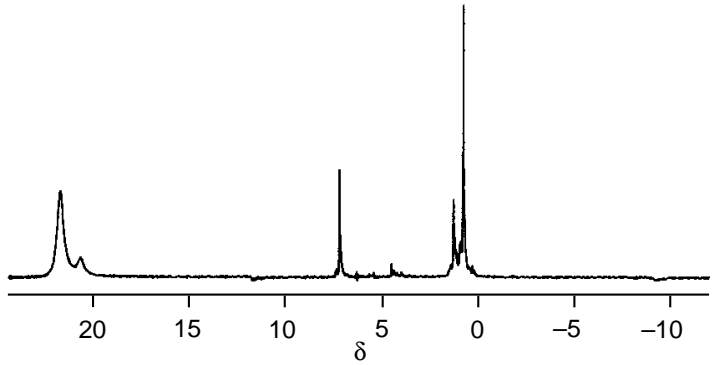

Fig. 1 Room-temperature ${ }^{1} \mathrm{H}$ NMR spectrum of the products of reaction (1); solvent $\mathrm{C}_{6} \mathrm{D}_{6}$ 


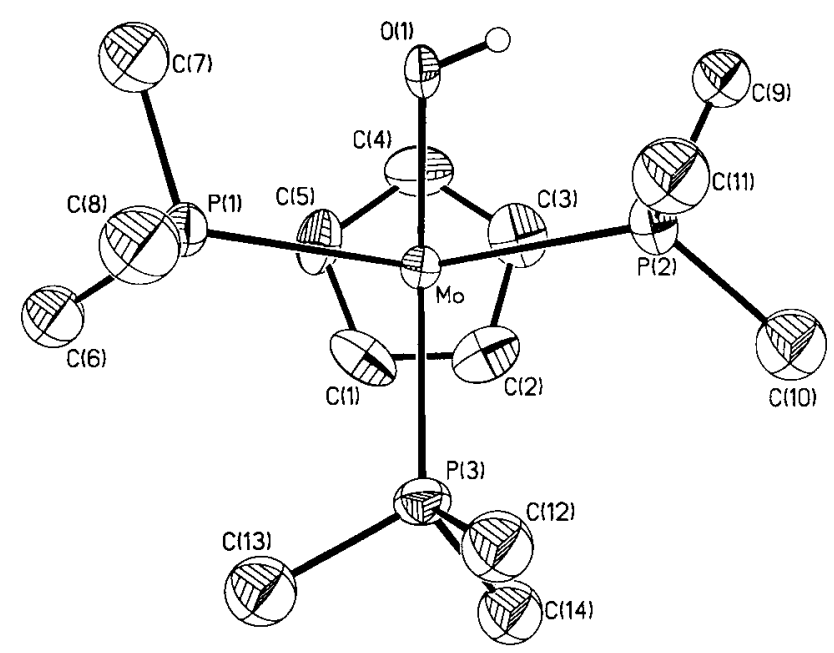

Fig. 2 Top view of the cation in compound 2. Ellipsoids drawn at $30 \%$ probability. Selected bond lengths $(\AA)$ and angles $\left({ }^{\circ}\right)$ : Mo-P(1) 2.4530(12), Mo-P(2) 2.4984(12), Mo-P(3) 2.4741(11), Mo-O(1) 2.084(2), Mo-Cp 1.980(4); P(1)-Mo-P(2) 94.19(5), P(1)-Mo-P(3) 93.21(4), P(1)-Mo-O(1) 139.27(10), P(1)-Mo-Cp 108.5(1), P(2)-Mo-P(3) 132.81(4), P(2)-Mo$\mathrm{O}(1)$ 71.53(8), P(2)-Mo-Cp 110.7(1), P(3)-Mo-O(1) 72.75(8), P(3)-Mo$\mathrm{Cp} 110.8(1), \mathrm{O}(1)-\mathrm{Mo}-\mathrm{Cp} 112.2(2)$. $\mathrm{Cp}$ is the $\mathrm{C}_{5} \mathrm{H}_{5}$ ring centroid.

known to prefer the 17-electron configuration. ${ }^{21,28}$ The nature of the observed product 2 shows that a bis( $\mu$-hydroxo)-bridged $\left[\mathbf{1}_{2}\right]^{2+}$ complex would be unstable relative to the mononuclear 17-electron $\mathrm{PMe}_{3}$ adduct. The hydroxide proton in complex 2 can be reasonably expected to be acidic. Presumably, the presence of free $\mathrm{PMe}_{3}$ or other adventitious proton acceptors during the formation of $\mathbf{2}$ induces a deprotonation equilibrium to afford a neutral $\mathrm{Mo}^{\mathrm{III}}$ oxo species which is then easily oxidized by $\left[\mathrm{Fe}\left(\eta^{5}-\mathrm{C}_{5} \mathrm{H}_{5}\right)_{2}\right]^{+}$to afford the observed product 3 [eqn. (3)].

$\left[\mathrm{Mo}\left(\eta^{5}-\mathrm{C}_{5} \mathrm{H}_{5}\right)(\mathrm{OH})\left(\mathrm{PMe}_{3}\right)_{2}\right]+\mathrm{PMe}_{3}+\left[\mathrm{Fe}\left(\eta^{5}-\mathrm{C}_{5} \mathrm{H}_{5}\right)_{2}\right]^{+} \rightarrow$ $\left[\mathrm{Mo}\left(\eta^{5}-\mathrm{C}_{5} \mathrm{H}_{5}\right)(\mathrm{OH})\left(\mathrm{PMe}_{3}\right)_{3}\right]^{+}+\left[\mathrm{Fe}\left(\eta^{5}-\mathrm{C}_{5} \mathrm{H}_{5}\right)_{2}\right]$

$$
\begin{array}{r}
{\left[\mathrm{Mo}\left(\eta^{5}-\mathrm{C}_{5} \mathrm{H}_{5}\right)(\mathrm{OH})\left(\mathrm{PMe}_{3}\right)_{3}\right]^{+}+\left[\mathrm{Fe}\left(\eta^{5}-\mathrm{C}_{5} \mathrm{H}_{5}\right)_{2}\right]^{+} \stackrel{-\mathrm{H}^{+}-\mathrm{PMe}_{3}}{\longrightarrow}} \\
{\left[\mathrm{Mo}\left(\eta^{5}-\mathrm{C}_{5} \mathrm{H}_{5} \mathrm{O}\right)\left(\mathrm{PMe}_{3}\right)_{2}\right]^{+}+\left[\mathrm{Fe}\left(\eta^{5}-\mathrm{C}_{5} \mathrm{H}_{5}\right)_{2}\right]}
\end{array}
$$

In conclusion, we have reported here for the first time the existence and stability of terminal hydroxo complexes of paramagnetic organometallics of $\mathrm{Mo}^{\mathrm{II}}$ and $\mathrm{Mo}^{\mathrm{III}}$ in defiance of the possible dimerization with formation of hydroxo-bridges. For the dimerization process to occur, $\mathbf{2}$ would have to lose the stabilization of the $\mathrm{Mo}^{\mathrm{III}}-\mathrm{PMe}_{3}$ bond, whereas compound 1 would have to pay the price of pairing the electrons. Terminal hydroxo complexes of $\mathrm{Mo}^{\mathrm{IV}}$, on the other hand, have been previously reported.2,29-34

This research was supported by the US Department of Energy Office of Energy Research (grant DEFG0295ER14550) and the National Science Foundation (grant CHE-9508521).

\section{Footnotes}

* E-mail: poli@u-bourgogne.fr

$\uparrow$ By carrying out all operations under a dinitrogen atmosphere, solid $\mathrm{KOH}$ (pre-dried at $110^{\circ} \mathrm{C}$ and $6 \mathrm{mmHg}$ for $48 \mathrm{~h}$; ca. $300 \mathrm{mg}$, ca. $5.3 \mathrm{mmol}$ ) was added to a blue solution of $\left[\mathrm{Mo}\left(\eta^{5}-\mathrm{C}_{5} \mathrm{H}_{5}\right) \mathrm{Cl}\left(\mathrm{PMe}_{3}\right)_{3}\right](215 \mathrm{mg}, 0.507 \mathrm{mmol})$ in $6 \mathrm{ml}$ of thf. After stirring overnight at room temp., complete evaporation of the solvent from the yellow-brown solution yielded an oily residue, which was extracted into heptane $(3 \times 5 \mathrm{ml})$. An aliquot of this solution was dried under reduced pressure and the residue was investigated by ${ }^{1} \mathrm{H}$ NMR in $\mathrm{C}_{6} \mathrm{D}_{6}$ : $\delta 21.8$ (br, $w_{1 / 2} 90 \mathrm{~Hz}, 18 \mathrm{H}, \mathrm{Me}$ ), 20.3 (br, $w_{1 / 2} 75 \mathrm{~Hz}, 5 \mathrm{H}, \mathrm{C}_{5} \mathrm{H}_{5}$ ). Concentration of the heptane solution and cooling to $-80{ }^{\circ} \mathrm{C}$ did not separate any solid.

\$ Crystal data for $2: \mathrm{C}_{14} \mathrm{H}_{33} \mathrm{BF}_{4} \mathrm{MoOP}_{3}, M=493.06$, orthorhombic, space group Pna $2_{1}, a=20.525(5), b=13.380(4), c=7.9740(7) \AA, U$ $=2189.9(9) \AA^{3}, Z=4, D_{\mathrm{c}}=1.496 \mathrm{Mg} \mathrm{m}^{-3}, \mu(\mathrm{Mo}-\mathrm{K} \alpha)=0.851 \mathrm{~mm}^{-1}$,
$2 \theta_{\max }=49.96^{\circ}, \omega-2 \theta$ scan mode, $\lambda=0.71073 \AA, T=293(2) \mathrm{K}$, $R_{1}=0.0353\left(w R_{2}=0.0734\right)$ for all data, $R_{1}=0.0267\left(w R_{2}=0.0567\right)$ for 226 parameters and 3339 observed $[I>2 \sigma(I)]$ data $(3712$ collected and independent reflections). Atomic coordinates, bond lengths and angles, and thermal parameters have been deposited at the Cambridge Crystallographic Data Centre (CCDC). See Information for Authors, Issue No. 1. Any request to the $\mathrm{CCDC}$ for this material should quote the full literature citation and the reference number $182 / 429$.

$\S$ The ${ }^{1} \mathrm{H}$ NMR properties match with those reported 27 31P NMR $\left(\mathrm{CD}_{3} \mathrm{COCD}_{3}\right): 13.8$. The identity of this compound is also verified by an $\mathrm{X}$-ray crystallographic study, which will be reported separately.

\section{References}

1 M. E. Falkley and A. Pidcock, J. Chem. Soc., Dalton Trans., 1977, 1444.

2 V. Albano, P. Bellon, G. Cini and M. Manassero, Chem. Commun., 1969, 1242.

3 U. Sartorelli, L. Garlaschelli, G. Ciani and G. Bonora, Inorg. Chim. Acta, 1971, 5, 191.

4 M. Herberhold, G. Süß, J. Ellermann and H. Gäbelein, Chem. Ber., 1978, 111, 2931.

5 G. L. Hillhouse and J. E. Bercaw, J. Am. Chem. Soc., 1984, 106, 5472 .

6 S. A. Al-Jibori, J. Organomet. Chem., 1996, 506, 119.

7 V. V. Grushin and H. Alper, Organometallics, 1996, 15, 5242.

8 T. G. Appleton and M. A. Bennett, Inorg. Chem., 1978, 17, 738.

9 D. P. Arnold and M. A. Bennett, J. Organomet. Chem., 1980, 199 119.

10 D. P. Arnold and M. A. Bennett, Inorg. Chem., 1984, 23, 2110.

11 C. T. Kan, P. B. Hitchcock and R. L. Richards, J. Chem. Soc., Dalton Trans., 1982, 79.

12 J. L. Cihonski and R. A. Levenson, Inorg. Chem., 1975, 14, 1717.

13 J. Böhmer, G. Haselhorst, K. Wieghardt and B. Nuber, Angew. Chem., Int. Ed. Engl., 1994, 33, 1473.

14 F. Abugideiri, M. A. Kelland, R. Poli and A. L. Rheingold, Organometallics, 1992, 11, 1303.

15 F. Abugideiri, J. C. Fettinger, D. W. Keogh and R. Poli, Organometallics, 1996, 15, 4407.

16 L.-S. Wang, J. C. Fettinger and R. Poli, J. Am. Chem. Soc., in the press.

17 R. T. Baker, J. C. Calabrese, R. L. Harlow and I. D. Williams, Organometallics, 1993, 12, 830.

18 M. Luksza, S. Kimmer and W. Malisch, Angew. Chem., Int. Ed. Engl., 1983, 22, 416.

19 F. Abugideiri, D. W. Keogh and R. Poli, J. Chem. Soc., Chem. Commun., 1994, 2317.

20 R. Poli, Chem. Rev., 1996, 96, 2135.

21 R. Poli, J. Coord. Chem. B, 1993, 29, 121.

22 K. Wieghardt, M. Hahn, W. Swiridoff and J. Weiss, Inorg. Chem., 1984, 23, 94.

23 K. Wieghardt, M. Guttmann, P. Chaudhuri, W. Gebert, M. Minelli, C. G. Young and J. H. Enemark, Inorg. Chem., 1985, 24, 3151

24 A. G. Sykes, in Comprehensive Coordination Chemistry, ed. G. Wilkinson, R. D. Gillard and J. McCleverty, Pergamon, Oxford, 1987, ch. 36.1 .

25 K. Wieghardt, U. Bossek, A. Neves, B. Nuber and J. Weiss, Inorg. Chem., 1989, 28, 432.

26 D. T. Richens and A. G. Sykes, Inorg. Synth., 1985, 23, 130.

27 M. Brookhart, K. Cox, F. G. N. Cloke, J. C. Green, M. L. H. Green, P. M. Hare, J. Bashkin, A. E. Derome and P. D. Grebenik, J. Chem. Soc. Dalton Trans., 1985, 423.

28 I. Cacelli, D. W. Keogh, R. Poli and A. Rizzo, New J. Chem., 1997, 21, 133.

29 K. Prout, T. S. Cameron, R. A. Forder, S. R. Critchley, B. Denton and G. V. Rees, Acta Crystallogr., Sect. B, 1974, 30, 2290.

30 P. R. Robinson, E. O. Schlemper and R. K. Murmann, Inorg. Chem., 1975, 14, 2035.

31 M. R. Churchill and F. J. Rotella, Inorg. Chem., 1978, 17, 668.

32 M. Berry, N. J. Cooper, M. L. H. Green and S. J. Simpson, J. Chem. Soc., Dalton Trans., 1980, 29.

33 K. Wieghardt, G. Backes-Dahman, W. Holzbach, W. J. Swirdoff and J. Weiss, Z. Anorg. Allg. Chem., 1983, 499, 44.

34 T. Adachi, D. L. Hughes, S. K. Ibrahim, S. Okamoto, C. J. Pickett, N. Yabanouchi and T. Yoshida, J. Chem. Soc., Chem. Commun., 1995, 1081. 